\title{
Negotiating Widowhood and Female Agency in Seventeenth-Century Hungary
}

\author{
Gabriella Erdélyi \\ Research Centre for the Humanities \\ erdelyi.gabriella@btk.mta.bu
}

The case study focuses on the tactics of aristocratic women to negotiate their familial roles and identities primarily as wives and widows. By reading closely the rich family correspondence of the Várdai-Telegdi family in the first half of the seventeenth century and concentrating on the intensive negotiating period between getting widowed and remarrying the study argues that the role of the go-between and the marginal status of women in the patrilineal and patriarchal family created some space for them to maneuver. Moreover, the cultural context of female familial roles and ties (mother and daughter, mother-in-law and daughter-in-law, half-sisters) was the female court, which created horizontal and intimate ties between women, which also empowered them.

Keywords: female agency, negotiating female roles, female courts, family network, halfsisters, mother-daughter relationship, emotional practices, letter exchange

\begin{abstract}
My sweet beloved lady mother, I wish our Lord God had allowed me to write better news for your Grace, my beloved husband was summoned by our Lord God a week ago, leaving us, my poor [...] child and me in my present condition [i.e. she was pregnant] rather lonely, I beg your Grace for the living God that your Grace would not leave me alone, but would instead visit me. ${ }^{1}$
\end{abstract}

In the first days of her widowhood, the 17-year old Krisztina Nyáry shared with her mother, Kata Várdai, her painful feeling of being an outsider in both of her families: after having lost her husband, she remained alone among her late husband's kin, while she also had to request support from her mother, who lived far away from her. The present article looks at the ways in which early modern aristocratic women maneuvered in their intermediate position between their natal and marital families. How did they mediate as wives, and how did they use their roles as mediators for their self-fashioning and their individual purposes? How did they negotiate their liminal status as widows to gain support and reintegrate into shifting family networks? Like births and marriages, deaths

1 Krisztina Nyáry to Kata Várdai. Zsolnalitva (Lietava, Szlovákia), October 26, 1621. MNL OL, P 707, Missiles, no. 10699. 
were followed by an intensive negotiating process among family members (on which the letter cited above touches), resulting in the reconfiguration of the family network. Therefore, in this article I focus on these periods of intensive bargaining in the life-cycles of the families to which Krisztina belonged. ${ }^{2}$

The protagonist of the following case study will be Krisztina Nyáry (1604 41), whose life, however, was fairly exceptional. Following the untimely death of her first husband, Imre Thurzó (1598-1621), his relatives pushed her aside. She was not only denied to receive the right of tutorship of her two little daughters, but, with the explicit aim of ensuring that her daughters would be raised as Lutherans (Krisztina was Calvinist), their daily care and upbringing was also entrusted to their paternal grandmother. ${ }^{3}$ This was a fairly extraordinary turn of events, since in Hungary as well as elsewhere in Europe widowed mothers were considered legitimate and capable tutors of their half-orphaned children, who were seldom separated from their mothers, especially at such a tender age. Also, instead of widowed mothers, the remarried mothers tended to be stigmatized as "cruel" and divested of the right to serve as tutors. ${ }^{4}$

By looking closely at this exceptional case, I aim to better understand typical contemporary concepts and everyday practices within the family. ${ }^{5}$ I will draw on the argument that familial roles are cultural constructs and have culturally distinct dynamics. It has been repeatedly argued that the maternal role of early modern aristocratic women was overshadowed by their role as wives in the patriarchal family. In other words, husbands expected their wives less to perform their maternal duties and more to fulfil services in the interest of their new families acquired through marriage. In short, female identity (as opposed to male identity) was more decisively shaped by the social bond created through marriages than the blood tie of maternity. ${ }^{6}$ How did Krisztina Nyáry, widowed in pregnancy and with an eight-month-old baby, maneuver in the spaces and gaps created by the web of familial expectations and ties? Drawing on the letters exchanged among family members, I offer a portrait of her in her natal family fulfilling the role

2 See Broomhall and Van Gent, Gender, Power and Identity.

3 See for example Duchonová, "Nói családi szerepek."

4 Horn, "Nemesi árvák a kora újkorban." On the case of an elite widowed mother raising her own children, see also Balogh, "Özvegység, újraházasodás és testvéri kapcsolatok.” On how and why remarrying mothers were stigmatized as "cruel" by their children and marital family members, see: Klapisch-Zuber, "The 'Cruel mother'."

5 For the meaning of the concept "exceptional normal" proposed by Italian microhistorians for the problem of representativity of exceptional cases, see Peltonen, "Clues, Margins, and Monads."

6 Chabot, "Seconde Nozze e Identita Materna," 495-96; Harris, English Aristocratic Women, 100, 107. 
of adult daughter and sister and as daughter-in-law in her relationship with her mother-in-law, Erzsébet Czobor. ${ }^{7}$

In Krisztina's natal family, the head of the family was Krisztina's widowed mother, Kata Várdai (1570-1630). Kata Várdai had played this role since losing her second husband, Pál Nyáry, in1607. In the 1610s and 1620s, she lived together with her adult daughter from her first marriage, Anna Telegdi (1589-1635), in the old Várdai-family residence, the castle of Kisvárda in the eastern region of Habsburg Hungary, next to the Principality of Transylvania. Their unusual coresidence resulted from the fact that, in 1609, Kata Várdai had her 20-year-old daughter Anna marry her stepbrother, István Nyáry, who was the son of Kata's second husband, Pál Nyáry. The stepsibling match, as usual, promoted both the economic and emotional integration of the stepfamily. ${ }^{8}$ The step-siblings, Anna and István, were close to each other in age, and as they had been living together as part of the same household for a decade, they knew each other well. The newly married couple found it entirely natural to remain in "beautiful Várda," in spite of the fact that they had numerous estates to choose from. ${ }^{9}$ Thus, Anna's half-sister Krisztina, who was five years old at the time, got a 19-year-old surrogate mother in the person of her half-sister and a 24-year-old surrogate father in her brother-in-law. This cohabitation of the half-sisters came to an end in 1618, when Krisztina left Kisvárda. Kata Várdai, always keeping a sharp eye out for a promising match for her daughter, managed to catch the attention of Imre Thurzó, the talented and immensely wealthy son of the late palatine. In the autumn of 1617, Imre and Krisztina, who was only 13 years old at the time, were engaged, and one year later, they were married. ${ }^{10}$ As custom dictated, Krisztina moved in with her husband's family in Biccse (today Bytča, Slovakia), which lay in the western region of Habsburg Hungary.

The asymmetry in the position of the half-sisters provides a good opportunity for a variety of observations. In the case of Anna, the fact that her natal and marital families merged and she remained in her natal home

\footnotetext{
7 Forty-eight letters written by Krisztina to her mother have survived from the years between 1618 and 1624 (MNL OL, P 707, no. 10661-10708), while all the letters written by Kata Várdai to Krisztina were lost. We know of nine letters written by Krisztina to her sister from the years between 1619 and 1633 (MNL OL, P 707, no. 9696-9704), seven of which are dated prior to 1624. All of Anna's replies are lost. On the correspondence between Krisztina Nyáry and Erzsébet Czobor, see Duchonová, "Női családi szerepek." 8 For more on the practice of stepsibling marriages, see Erdélyi, "Stepfamily Relations in Autobiographical Writings," 146-67 and Warner, "Conclusion," 239-42.

9 "Beautiful Várda”: Anna Telegdi to Kata Várdai. Várda, April 4, 1622 (MNL OL, P 707, no. 10868).

10 Ipolyi, Bedegi Nyáry Krisżtina.
} 
as a married woman resulted in an exceptionally close and intimate but also increasingly hierarchical mother-daughter relationship, on which I have written in detail in another study. ${ }^{11}$ Krisztina, in contrast, played the common mediating role of married women between their natal and marital families. The dual use of names is one of the indications of the double identities of wives. ${ }^{12}$ Accordingly, the newlywed Krisztina signed her letters Niari Christina, while others referred to her as "my lady Mrs. Thurzó." How much influence and freedom of movement did Krisztina have in the court of the Thurzó family, and how did she manage to maneuver and negotiate this space between two dominant mother figures, Kata Várdai and her mother-in-law, Erzsébet Czobor? It seems reasonable to surmise that the role of the go-between and the marginal status of women in the patrilineal family created some space for them to maneuver. Below, I examine the tactics used by the extremely young widow Krisztina, who has been depicted by historians as simple-minded, ${ }^{13}$ when she mediated between the two very dominant mother figures governing the two families.

The relationship of the half-sisters was asymmetrical not only in terms of their age (Anna was 14 years older than Krisztina), but also with regard to social rank and wealth due to the differences of their paternal and marital families. Historians tend to assume that differences and hierarchies between sisters and brothers, which were typical in patriarchal families at the time, led to conflicts and rivalries. ${ }^{14}$ We will thus observe whether and how, instead of or alongside the love and solidarity one would expect between sisters and half-sisters, rivalry and negative emotions found expression. It becomes clear from the family correspondence that the cultural backdrop of the mother-daughter, mother-inlaw, daughter-in-law, and sister relationship was the female aristocratic court in more general terms, the female domestic community. How did these alternative female friendship and kinship ties influence women's roles and identities as wives, widows, mothers, and daughters-in-law in the patriarchal family?

\footnotetext{
11 Erdélyi, "Anyaság a kora újkorban."

12 On the uses of names by aristocratic women, see Péter, "Az asszony neve." In the signatures at the ends of their letters, the women of the aristocracy usually used their Christian names and the names they had inherited from their fathers. Only rarely did they also use their husband's names with the "né" suffix (which in Hungarian means, roughly, "woman of" and which corresponds, again roughly, to the title Mrs. in English). This use of the husband's name with the suffix "né" was used only in exceptional cases on its own.

13 Péter, Esterbáay Miklós.

14 Ruppel, Verbündete Rivalen.
} 


\section{Between "Two Mothers"}

When Krisztina suddenly found herself with "two mothers," the motherdaughter relationship became a triangle. In this triangle, Erzsébet Czobor also corresponded with Kata Várdai, whom she informed about her daughter's pregnancy:

My loving daughter-in-law and my sweet little grandchild and maiden daughter are in good health [...]. I would also like to let you know that on Michaelmas my loving daughter-in-law learned of the gift bestowed by God, whom let his holy majesty allow her to bear in peace joy and bring happily into this world and with your graces reach this time in good health. ${ }^{15}$

Krisztina found herself in the role of mediator between the two mothers. She delivered greetings and letters from the one to the other. As she wrote in one letter, "My dear heart, My Lady Mother, I have given the letter which your grace wrote to my Lady her Greatness."16 In other words, Kata Várdai put the letter she had written to Erzsébet Czobor in with the letters she had written to her daughter, and Krisztina passed this letter on to her mother-inlaw. Furthermore, Krisztina knew of the letters written by her mother-in-law to her mother, and she adjusted her own letters accordingly, both from the perspective of timing ${ }^{17}$ and from the perspective of their content: "I know that My Lady her Greatness wrote of our news."18 And as she was a member of the women's court of Biccse, she had to adapt in many ways to this life and, first and foremost, to the head of the court, her mother-in-law. On one occasion, she felt obliged to offer an explanation as to why she had not written for two weeks:

I was given four letters from My heart, my Lady Mother to which I could not reply, I beg your grace to forgive me for not having replied,

15 Erzsébet Czobor's letters to Kata Várdai, which, with the exception of the last two, were written while her son was still alive: MNL OL, P 707, no. 10278-10309 (1618-February, 1622). On Krisztina's pregnancy: MNL OL, P 707, no. 10308, the end is missing (after August 9, 1621). Kata Várdai’s letters to Erzsébet Czobor: National Széchényi Library, Manuscript Collection, Fol. Hung. vol. 2638/2. (The collection of copies of letters by Hungarian women) fol. 167, 210-11, 337-38, 415 (1617-1621).

16 Krisztina Nyáry to Kata Várdai, April 28, 1620 (MNL OL, P 707, no. 10661).

17 See for example: "My sweet heart, my Lady Mother, as my Lady her Greatness sent letters to Tokaj, I too wanted to visit your grace and inquire as to your grace's health and how your grace is faring." Krisztina Nyáry to Kata Várdai. Zsolnalitva, January 7, 1620 (MNL OL, P 707, no. 10691).

18 Krisztina Nyáry to Kata Várdai. Zsolnalitva, October 31, 1619 (MNL OL, P 707, no. 10668). 
because My Lady her Greatness and my husband his grace were undergoing purgations, and I had to busy myself with them, and this is why I could find no time to write to your Grace. ${ }^{19}$

Thus, Krisztina did not maintain an independent correspondence with her mother. She did not have anyone to deliver letters on her behalf, but rather wrote when the court messenger traveled to her mother's court. Her letters concerned news of the events which took place in the women's court of Biccse, including news of visitors, illnesses, weddings, and funerals. This kind of collective character of her letters is particularly remarkable: indeed, instead of a letter exchange between two individuals, the female court community of Biccse corresponds with that of Várda. ${ }^{20}$ It is common knowledge that early modern letter-writing (the writing, circulation, and reading of letters) was a collective social practice. ${ }^{21}$

It is of particular interest in this case that, beyond the family network, the female court also functioned as an "epistolary community." 22 At the beginning of her letters, Krisztina often addressed her half-sister and her mother, and at the end she sent her greetings, ${ }^{23}$ and she also passed on the oral greetings from her mother-in-law, her unmarried sisters-in-law (the "misses" who were still living at home), her married sisters-in-law, who were visiting their mother, ${ }^{24}$ as well as other female retainers such as the nurses and wet-nurses, and the noble maidens ("young ladies"): "My dear, my Lady Mother, Lady Erdődi is here, ${ }^{25}$ and Lady

19 Krisztina Nyáry to Kata Várdai. Biccse, June 2, 1620 (MNL OL, P 707, no. 10690). Her last letter before this was written on May 16.

20 Geographically it meant a distance of circa 500 kilometers, as Biccse is situated in the northwestern region of what was Habsburg Hungary, while Várda (Kisvárda today in Hungary) was in the eastern parts. However, during these years, Várda became attached to the principality in the peace treaty of Nikolsburg (1621) as a result of the military victories of Gábor Bethlen, Prince of Transylvania (1613-1629), over Ferdinand II Habsburg, King of Hungary (1618-1637) during the Thirty Years' War.

21 Schneider, The Culture Of Epistolarity.

22 On this concept, see ibid, 22-28.

23 For instance, at the beginning of the letter written on December 13, 1620: "I hope that the good Lord keeps your graces in good health for many years, both my loving sister and my Lady." (MNL OL, P 707, no. 10662).

24 In the school which she maintained in her court in Biccse, the grandmother raised many grandchildren, boys and girls, and her married daughters often used her court in part for this reason. See Bódai, "Szülöi szerepek és gondoskodás." Czobor Erzsébet Mint Anya És Mostohaanya." And Erzsébet Czobor's letters to Kata Várdai: MNL OL, P 707, no. 10278-309.

25 György Thurzó and Erzsébet Czobor's eldest daughter, Borbála Thurzó’s first husband (they were married in 1612 and he died in 1620) was Kristóf Erdődy. 
Vízkelety ${ }^{26}$ arrived yesterday, they offer their services to your grace. Similarly, the three maidens ${ }^{27}$ offer their services with great love." 28

Krisztina brought the so-called "old woman” (Lady Bogáti), the head of her court, from Várda with herself, so she repeatedly asked her mother to arrange for payment of her salary: "I do now know where the payment for my old woman will come from, as here in the upper regions there are other customs, they say, and they do not want to pay her, but rather my sweet lady mother, your grace agreed with her about her payment, so I ask your grace that your grace not leave the poor thing on her own." 29 She also asked her to send news of her children, "for she longs for her children so sadly, the poor thing." ${ }^{30}$ As was characteristic of her, Kata Várdai entrusted her younger daughter Krisztina's request to her elder daughter, Anna, and Anna turned to her cousin, Erzsébet Szokoly, who took care of the children's placement: "Your grace should bring the sons of the poor Lady Bogáti with you [...] my lady fears for their poor mother that she will grow sad, thus your grace, my sweet loving lady should act the way that it be avoided, and Lady Bogáti may serve with good heart around my sweet sister." 31 By the time they had come to an agreement, the "old woman" had returned to her children: "My heart, my Lady Mother, with regards to the affairs of the old woman, there is one who was brought from Léva who twirls around me quite well, but Lady Bogáti has left me, she by no means remained with us. I serve your grace's good will, but it is already done." 32 With this, the ties which bound Krisztina to Várda and her mother were further loosened, and the ties which bound her to her new home, her new "mother," and the women's court of Biccse were tightened, and we are offered glimpses into the functioning of the network of pragmatic relationships among these women.

26 György Thurzó and Erzsébet Czobor’s daughter, Mária Thurzó, wife of Mihály Vizkelety (15941662).

27 Erzsébet Czobor's younger, still unmarried daughters, Anna Thurzó, Katalin Thurzó, and a third who may have been named Erzsébet.

28 Krisztina Nyáry to Kata Várdai. Biccse, Saturday 1619 (MNL OL, P 707, no. 10665).

29 Krisztina Nyáry to Kata Várdai. February 10, 1619 (MNL OL, P 707, no. 10677).

30 Ibid. On April 24, she asked her mother again: "As for what concerns the affair of my old woman, indeed she would love to go and see her children, so my sweet loving soul, my Lady Mother, send to their home to find out how they are, and your grace write it to me.”(MNL OL, P 707, no. 10675.)

31 Anna Telegdi to her niece, Erzsébet Szokoly. Várda, April 20, 1619 (MNL OL, P 707, no. 9216).

32 Krisztina Nyáry to Kata Várdai. Zsolnalitva, January 15, 1620 (MNL OL, P 707, no. 10683). 
With her advantageous marriage Krisztina had become the wife of a count, and and thus had risen from the ranks of the barons to the ranks of the counts. ${ }^{33}$ This had changed her position in her natal family, and this is palpable in the communication between Krisztina and her mother. For example, as opposed to her elder sister, she does not hesitate to make frequent requests to her mother, which indicates a shift towards a more equal relationship with her mother.

Some of her letters to her mother were not written in her hand. Rather, she used the services of a scribe, which was another act with which she negotiated her subordination as a daughter. ${ }^{34}$ She anticipated that this act would be met with rebuke: "My sweet loving soul, my lady mother, forgive me, your grace, that I did not write your grace with my own hand, I could not write with my own hand, but after this I shall." 35 Beyond the rhetoric of daughterly subordination and obedience, her use of emotional language is remarkable, as it mirrors the emotional language of her mother and thus again positions her vis-à-vis her mother on more equal terms. The newlywed young wife shared her feelings of sadness with her mother in the following words: "Even if I had no other grief, I would still lament that your grace is far from me, my sweet lord is in the camp, he writes nothing to us, our only affair is the many thoughts day and night." 36 Krisztina wrote many times of the abandonment she suffered as a member of her husband's family, and she expressed her longing for her mother's love many times:

My sweet heart, my Lady Mother, I understand from your grace's letter that I wrote that I am of heavy heart in my sweet Husband's absence, were I closer to your grace, your grace would take me to her, and certainly I would have no grief were I with your grace. Your grace also wrote that your grace can show no motherly love to me, my dear heart, My Lady Mother, I believed that your grace wished me well, I have no doubt. ${ }^{37}$

The way she shares her feelings suggests that mother and daughter had a confidential relationship, and it also seems expressive of a desire to maintain an emotional bond that would bridge the distance between them: "My loving heart,

33 György Thurzó invented the Hungarian title of count, drawing on the German example, and in 1606, he became the first person on whom this title was bestowed. Pálffy, "A Thurzó család."

34 Her half-sister, Anna Telegdi wrote all her letters to their mother herself.

35 Krisztina Nyáry to Kata Várdai. Biccse, March 16, 1619 (MNL OL, P 707, no. 10676).

36 Krisztina Nyáry to Kata Várdai. Zsolnalitva, October 31, 1619 (MNL OL, P 707, no. 10668).

37 Krisztina Nyáry to Kata Várdai. Zsolnalitva, January 15, 1620 (MNL OL, P 707, no. 10683). 
my Lady Mother, I also understand from your grace's letter that your grace is glad to hear of my health, even if I am so far away, I believed this, even if your grace does not write it to me." 38 In other words, she sensed her mother's love for her even in the absence of words.

Krisztina's sense of alienation in her husband's family's court was somewhat eased by her close ties to some of the members of the female court. She cherished a close friendship with her maiden sister-in-law, Katica Thurzó. This friendship must have inspired the rare comic tone of one of her letters, in which she used playful irony deriving from overstatement: "My dear Katica Thurzó offers her loyal, perfect, true, humble, and lifelong services to your Grace as her beloved, kind, and above all beautiful lady and sister. She asks your Grace to keep her among all your Grace's servants as the smallest dishwashing maidservant." ${ }^{39}$ This letter suggests that these domestic female alternative kinship and friendship ties, including the bonds between sisters and sisters-in-law, may have made the marginal status they had in the patriarchal family more endurable for women.

Krisztina had to ask her mother, who lived a great distance from her, to send her a prayer-book for her comfort in her time of mourning, since she could not turn to her mother-in-law with her emotional, spiritual, and moral needs, as her mother-in-law did not strive to play the maternal role in emotional terms: "My dear heart, my lady mother, I ask your Grace to send me a prayer-book, a Hungarian one, I will return it to your Grace as my beloved lady mother, since the one I brought with myself, while I was lying [when she was confined to bed before giving birth] has been lost, I could never find it." "I0 István Nyáry, Krisztina's half-brother and brother-in-law, escorted the mourning mother and the "body of the poor lord" from the court of Biccse to Zsolnalitva, the place of the burial. Although he wanted to calm his anxious wife (Anna, Krisztina's half-sister) by reassuring her that Krisztina was being shown due attention by her marital relations, his words seem to suggest, rather, the very uncertain place Krisztina had in her late husband's family: 'Thank God my lady sister [Krisztina] is moderately well in her bitter condition due to the fact that the Old Lady her Grace [Krisztina's mother-in-law] avoids crying in front of her, since my Lady Sister is in a heavy condition [she is pregnant] and there is a great hope that Lord God will bless her Grace with a boy." ${ }^{\prime 1}$

38 Krisztina Nyáry to Kata Várdai. Biccse, Saturday 1619 (MNL OL, P 707, no. 10665).

39 Krisztina Nyáry to Anna Telegdi. Biccse, May 29, 1619 (MNL OL, P 707, no. 9696).

40 Krisztina Nyáry to Kata Várdai. Zsolnalitva, May 16, 1622 (MNL OL, P 707, no. 10704).

41 István Nyáry to Anna Telegdi. October 30, 1621 (MNL OL, P 707, no. 9679a). 
Following the death of her only son, the most pressing issue for widow Erzsébet Czobor as head of the family was to secure the transfer of wealth to the next generation, if possible on the male line, so she was temporarily concerned about the health of her pregnant daughter-in-law. When Krisztina gave birth to a girl, however, her hopes were dashed. As Krisztina did not help secure the continuity of the Thurzó male line, she lost what little prestige she had had in her marital family. Consequently, the Thurzós not only refused to acknowledge her right to tutor her daughters and rejected any claim on her part to their considerable inheritance, but in order to secure their Lutheran faith in the future, their upbringing was entrusted to their paternal grandmother. ${ }^{42}$ This was unusual, since widowed mothers were usually deprived of their right to serve as tutors to their underage children only if they remarried, and they often could continue to provide daily care for their daughters and govern the schooling of their sons in their reconstituted families as well. ${ }^{43}$ In other words, the paternal families of underage half-orphans were concerned not about the influence of widowed mothers on the transmission of wealth, but rather about the influence of their new husbands, who became the stepfathers of the children in question. ${ }^{44}$ This kind of fear is articulated as a charge during the court trial against Krisztina's new husband, Miklós Esterházy, over the tutorship of the Thurzó daughters: "Ezterházy is eager for the estates of the orphans [...]. This title also deprives the woman of the tutorship, since she has also changed her name of her husband. And she has bound herself to a person eager to acquire the orphans' estates". 45

But what fed these strong fears of the powerful Thurzó family when the woman they were dealing with was a 17 -year-old widow? It seems improbable that they were indeed worried that much about the Lutheran upbringing of the girls under the care of a Calvinist mother, which they claimed before royal judges. ${ }^{46}$ Rather, they probably saw Krisztina as a risk factor in their campaign to receive the right of cognatic inheritance from the king, since the only tie between the two dynasties ${ }^{47}$ had been broken with the death of Imre Thurzó, which

42 See for example: Duchonová, "Nói családi szerepek."

43 For some examples, see Horn, "Nemesi árvák," 64-68.

44 On the collective fears concerning stepfathers, which found expression in law, see Warner, "Conclusion."

45 MNL OL, P 108, Repositorium 29., Fasc. B., no. 26., fols 1-7.

46 MNL OL, P 108, Rep. 29., Fasc. B., no. 28., fol. 14-18.

47 I use the concept of dynasty as an equivalent of the term familia, which was used at the time to denote lineages deriving from the same ancestor. Thus, I extend the meanings of the term from its narrower usage (a term for ruling families) to economically and politically powerful aristocratic family networks. 
immediately turned the allied in-laws into enemies ("atyafiakból idegenek"). Repeated marriages between dynasties were remedies of the fragility of family connections and served to prevent or resolve conflicts by stabilizing alliances. ${ }^{48}$ The marriage arranged by Kata Várdai for her 14-year-old daughter three years earlier had constituted a venturous step: the bride had been the best possible match in the country at the time, but the Thurzós had been outsiders to the dense network of alliances among the Várdai-Telegdi-Nyáry-Szokoly-MelithCsapy families.

As a result, following the death of her husband, Krisztina's ties to her marital family were open to negotiation, but it seems that she did not trust her mother to come to her aid and provide support for her either. In this "liminal" moment, it was not at all evident that she belonged to her natal family. This bond was similarly open to negotiation, and in this process, in which their integration into or exclusion from the family was at stake, widows could play an active role. In the transitory period following the death of her husband, Krisztina tried to earn her mother's support by assuming the role of the helpless and vulnerable widow:

Your Grace can see that I am a feeble woman, who can trust no one apart from God, only in your Grace. One of my supports was taken away from me by God, I am helpless on my own. [...] My beloved Lady Mother, I ask you for the living God that your Grace would come to me. The testament of my beloved husband, who now rests with the Lord, is with me, which is another reason that your Grace should visit $\mathrm{me}^{49}$

Her cry for help fell on deaf ears. Kata Várdai seems to have enjoyed her daughter's defenselessness and humble plea, since she pretended not to have understood from the above letter that her daughter badly needed her help. Krisztina therefore had to repeat her request:

My heart is happy about your Grace's reassuring words in her letter, which I will return with my services. My God has visited enough sorrow upon me, but his sacred will must be fulfilled. My beloved Lady Mother, your Grace has also asked me to write to your Grace whether your Grace's visit was indeed necessary. My beloved Lady Mother, yes, it is absolutely necessary, since we have remained rather desolate in our present state. We do not know ourselves yet when the funeral will take

48 Spieß, Familie und Verwandtschaft.

49 Krisztina Nyáry to Kata Várdai. Zsolnalitva, October 26, 1621 (MNL OL, P 707, no. 10699). 
place, because nothing is ready yet for it. If your Grace comes up here, we will talk about it together ${ }^{50}$

Krisztina's mother had already refused to provide support for her on other occasions, and Krisztina had had to beg for things that adult daughters of the time would have expected from their mothers. In January 1621, she even had to remind her mother of the risks of her upcoming childbirth: "My Lady Mother, I still ask you not to spare your energy and to visit us up here, who knows whether Your Grace can ever see me again." 51 She had to entice her mother the same way following her husband's death. In this case, his testament, in which he made arrangements concerning the future of his widow and their daughters, served as the bait. Krisztina mentioned it in the post script: "My beloved Lady Mother, my only beloved husband has ordered in his life that I should not show it to anyone, only your Grace, thus if your Grace refuses to visit us, we will go against his last will." Krisztina thus strove to earn her mother's support by presenting herself as vulnerable and her mother as indispensable. ${ }^{52}$

For Kata Várdai, it was not self-evident that she would remain at her daughter's side when Krisztina gave birth. In October 1620, István Nyáry, her son-in-law, urged his wife Anna to send her mother to be at her younger daughter's side:

I would very much like my dear beloved soul, if my Lady her Highness [Kata Várdai] would come here by the time Mrs. Imre Thurzó needs to stay in bed [to give birth], perhaps His Majesty [the Prince of Transylvania] would also let me go in front of her Highness [Krisztina, who was approaching the last month of her pregnancy] and also home. My lord Imre Thurzó has shown me today her mother's letter, in which she writes that my sister has not got more than five or six weeks before she gives birth. ${ }^{53}$

The son-in-law had to remind her of her maternal duties again, when Krisztina was close to giving birth for the second time: "With regards to your Highness's desire to leave, I do not see any possibility for your Highness's departure, since it would be very painful for my Lady Sister." 54

50 Krisztina Nyáry to Kata Várdai. Zsolnalitva, November 7, 1621 (MNL OL, P 707, no. 10700).

51 Krisztina Nyáry to Kata Várdai. Zsolnalitva, January 18, 1621 (MNL OL, P 707, no. 10696).

52 Krisztina Nyáry to Kata Várdai. Zsolnalitva, October 26, 1621, postscript (MNL OL, P 707, no. 10699).

53 István Nyáry to Anna Telegdi. Pozsony (Bratislava, Slovakia), October 21, 1620 (MNL OL, P 707, no. 9667).

54 István Nyáry to Kata Várdai. Szucsány, February 1, 1622 (MNL OL, P 707, no. 10659). 
Although Kata Várdai may not have been able to satisfy her daughters' emotional needs (most probably because of her own traumas she had suffered as a child), when she felt that her authority as mother was in danger, she vehemently defended it. When she was in conflict with her younger daughter and threatened to withhold her affections if Krisztina were to give in to her husband and convert from Calvinism to Lutheranism, she essentially was making a defensive show of her own power and prestige:

I beseech your grace, my sweet heart, Lady my mother, do not be cross with me for this issue of faith, for I have come to know my God and I want to remain in the true faith, as I do this not following my own head, but because I have read the Holy Scriptures and my beliefs are in accordance with them. My sweet heart, Lady my Mother, I also understand from your letter that your grace looks on Lady Erdődi ${ }^{55}$ as an example, Lord Erdődi, before he married her, took her hand and gave a letter of faith confirming that he would not trouble her over her faith. My sweet heart, my Lady Mother, your grace also wrote that Lady Thököly ${ }^{56}$ also did not leave her faith, because my sweet heart, my Lady Mother, they also took care for her. Your grace also writes in her letter that I have forgotten your grace's motherly admonitions. Lord forfend that I forget your grace's motherly admonitions, but I owe this to my God, and also that as long as I live, I strive to serve your grace with a true heart. ${ }^{57}$

According to the script for emotional blackmail, first Kata Várdai created a sense of fear in her daughter by accusing her of having defied her mother, and then she would withhold her motherly love ("do not be cross with me"). She would then try to appeal to her daughter's sense of reason or even jealousy by mentioning Krisztina's sisters-in-law (Borbála and Katalin Thurzó) as examples of women who, though they were in denominationally mixed marriages (to Kristóf Erdődy, a Catholic, and István Thököly, a Calvinist), nonetheless remained adherents of the faith they had received from their parents. ${ }^{58}$ Then, using the typical tool at the disposal of the emotionally manipulative, she would

55 On Borbála Thurzó, see footnotes 25 and 58.

56 György Thurzó and Erzsébet Czobor's daughter Katalin Thurzó (1601-1647) married István Thököly of Késmárk in 1620.

57 Krisztina Nyáry to Kata Várdai. Biccse, April 4, 1620 (MNL OL, P 707, no. 10693).

58 Regarding Borbála Thurzó's religious belonging, we know that she converted to Catholicism during her second marriage under the influence of her second husband, János Draskovics. Her first husband, Kristóf Erdődy, was buried in the chapter church of Nagyszombat (Tyrnava, Slovakia), which means that when he died, he belonged to the Catholic Church. Furthermore, several sources indicate that Katalin 
try to make her daughter feel guilty by accusing her of showing no regard for the religious upbringing she had been given ("Lord forfend that I forget your grace's motherly admonitions") and, in doing so, neglecting her duties as a daughter. ${ }^{59}$

For Kata Várdai, her daughter's religion was a question of immense importance, as her very prestige as a mother was at stake. By mentioning the Thurzó daughters, she was clearly also sending a message to Erzsébet Czobor, who may very well have had close knowledge of Krisztina's correspondence with her mother. If her daughters had remained true to the faith into which they had been born, then Kata Várdai's daughter clearly also should be granted the right to be left in peace on matters of religion. If Krisztina's actual commitment to her faith had been a question of importance to her mother, Kata Várdai never would have allowed her to marry first a Calvinist and then a Catholic.

Krisztina reacted with a show of confidence to her mother's attempts at emotional blackmail, which shows that she was not as closely dependent on her mother as her sister was and she was better able to protect herself. In order to reassure her mother, she reproduces the lesson she has probably heard many times also from her mother. Drawing on the polemical discourse of the era (and in doing so, showing herself to be resourceful and knowledgeable), she uses the only argument that was considered a legitimate explanation for the choice of faith. She claims that she has come to know the truth, which she came to know, furthermore, by reading the Scriptures. In other words, she made this decision not as the consequence of some miracle, but rather through intellectual endeavor. ${ }^{60}$ In short, she insists that she is not abandoning the Calvinist adherence to the truth which she came to know, as a child, by reading the Bible. She closes her letter with the following words:

My sweet heart, my Lady Mother, your grace wrote that my loving husband is indeed fortunate, I believe that my God saves his grace from all evil, and anything should happen I believe my God that your grace will not withhold your motherly love from me. ${ }^{61}$

Thurzó remained Lutheran and provided support for Lutheran publications. I would like to thank Borbála Benda for this information.

59 Emotional blackmail is used to create a sense of fear, guilt, and failure to fulfill obligations and, in doing so, to sway the person targeted to give in and submit to the other person's will instead of enduring these negative emotions. Forward and Frazier, Emotional blackmail.

60 This is the reasoning found in the Protestant and Catholic narratives of conversion at the time, both by women and by men. Erdélyi, "Confessional Identity."

61 Krisztina Nyáry to Kata Várdai. Biccse, April 4, 1620 (MNL OL, P 707, no. 10693). 
With this sentence, she deviates from her earlier argument according to which her free choice of faith can only be based on knowledge of the truth, and she writes instead of the influences of family ties and the conflicting pressures being put on her by her husband and her mother. In other words, here she speaks of her actual situation, although she uses the conditional mode. It is worth noting that she is actually saying the same thing here, in her own words, that she may have read in Péter Pázmány's narratives of female conversion: ${ }^{62}$ family compulsions stand in the way of following the truth one has realized. And while Pázmány, the Catholic archbishop and polemicist, calls on transcendent forces to help resolve this inner drama, Krisztina proposes the possibility of unconditional maternal love. At the same time asks her enraged mother (still using the conditional) to respond with unconditional love were Krisztina to defy the maternal will, or in other words were she chose to disobey her and convert. ${ }^{63}$ Thus, in the seventeenth century, the idea of conditional parental (paternal) and unconditional maternal love existed side by side, and Krisztina skillfully manipulated this in her conflict with her mother to gain some room for maneuver. By referring to her duties to God ("I owe this to my God") in her confrontation with her mother, Krisztina seems to put Kata Várdai against God himself.

Krisztina's assertiveness with her mother was facilitated by her intermediate position between her two families. Her intermediate position found expression very markedly when Krisztina lost her husband, and the two families became entangled in a fierce rivalry for control over the young widow. Though her motherin-law left Krisztina with no influence over her daughters, this did not mean that Krisztina was excluded entirely from her marital family. On the contrary, Erzsébet Czobor tried to secure the smooth intergenerational transmission of wealth by reintegrating Krisztina (and her considerable paternal and maternal inheritance) into the Thurzó dynasty. She wanted to arrange Krisztina's next marriage herself (instead of allowing her natal family to arrange it) within the circle of the Thurzó allies and in-laws. Below, I examine the stages of the rivalry between the mother and the mother-in-law, who as the heads of their families sought to strengthen their families' prestige and influence by forging a new alliance.

62 For example in his treatise entitled Nyolc Okok, or "Eight Reasons," which Pázmány wrote it in an effort to convert the aristocratic widow, Judit Révay. Erdélyi, "Confessional Identity," 476.

63 We do not actually know what happened, but it is possible that there was an attempt to convert Krisztina in Biccse. In the end, she converted to Catholicism in 1624 as Miklós Esterházy's wife. 


\section{The Rivalry between the Two Families for Influence over the Widow}

In 1622, Kata Várdai entrusted her motherly role for her daughter and granddaughters to her daughter's mother-in-law: "My dear beloved Lady, I entrust to your to Highness's maternal care, as if to my own eyes, my beloved orphaned ${ }^{64}$ daughter, together with her sweet children, and I ask from my heart your Highness not to withhold your Highness's motherly love and care, which your Highness has shown them so far. ${ }^{65}$ This gesture was intended to calm the furious matriarch, who had expressed her indignation when her rival, Kata Várdai, has proposed, as if offering a compromise, that she would take her daughter home with her and the granddaughters would be sent to the Viennese court. Unsurprisingly, Erzsébet was not appeased by the offer. In January 1623, she pressed her daughter-in-law to sign an agreement in which she forfeited any claim to the right to raise her own daughters. ${ }^{66}$

At the same time, Várdai started negotiations in the background, her intimate allies being her elder daughter and her husband. In February 1622, shortly before Krisztina gave birth to her second child, Várdai sent her son-in-law István Nyáry to meet with one of the highest dignitaries of the country. Nyáry wrote in one of his letters to her to confirm that he had received her instructions: "I have received your Highness's letter, I understand your Highness's order that I should talk and arrange my sister's affairs [Krisztina's affairs, his wife's half-sister] with my lord brother, Péter Révay. [...] I strive with all my heart to serve in all possible ways my beloved lady sister." ${ }^{\prime 67}$ Várdai also sought to "free" her daughter from the "captivity" of the Thurzó family. In 1623, she recurrently expressed her anxiety to her elder daughter over Krisztina's plight: "My sweet daughter, I have no rest day and night in my thinking about my poor sweet orphan, your younger

64 In the patriarchal noble family, only children who had lost their fathers, the head of the family, their male superior responsible for their wellbeing were legally considered orphans. Therefore, widowed women in Hungary were similarly called "orphans," and they referred to themselves as orphans, thus emphasizing their vulnerability. For more details, see Erdélyi, Özvegyek és árvák a régi Magyarországon.

65 I quote the letter from the biography of Imre Thurzó, in which the author does not tell us the date of the letter. Kubinyi, Bethlenfalvi gróf Thurzó Imre. https://mek.oszk.hu/05600/05613/html/. Last accessed on 2 July, 2020.

66 "Transaction between Krisztina and Erzsébet Czobor in the castle of Trencsén, in front of Szaniszló Thurzó, about the supporting, education and caretaking of the children." MNL OL, P 108, Rep. 29., Fasc. B., no. 31, fols 23-25, and fols 26-27. The Thurzós referred back to this "agreement" during the court trial over tutorship from 1624.

67 István Nyáry to Kata Várdai. Kassa, February 29, 1622 (MNL OL, P 707, no. 10658). 
sister, and how could we rescue her from that Purgatory" ${ }^{68}$ In another letter, she wrote "I am so very desperate about the fate of my poor orphan [...]. You could write me, my sweet daughter, what exactly they want, or we can speak about it when God brings you home. Somehow we must rescue your sweet sister from there." ${ }^{69}$

Meanwhile, Kata Várdai informed Krisztina that she would "try to please my relatives, which I will do by readily serving them." The advice she gave as Krisztina's mother may well have been a tool with which she sought to gain some time in preparation for the next battle in the war for influence over Krisztina and control of her future and for the negotiations taking place in background concerning her next marriage. By this time, Kata Várdai had a candidate for the groom, as is clear form comments made by Krisztina in one of her letters to her mother: "From your Grace's letter I understand that your Grace anxiously takes care of me, which I fully believe, since after God I trust only your Grace. My sweet heart, my lady mother, with regards to the Kassa affair, I ask your Grace to tell me more about it."70 The term "Kassa affair" is a reference to Kata Várdai's attempts in the city of Kassa (today Košice, Slovakia) at arranging Krisztina's second marriage.

At the same time, she asked her elder daughter to procure the approval of the prince of Transylvania for the marriage between and Krisztina this man, since the man was is in his service. Anna touches on this in one of her letters to her mother:

I understand your Grace's order concerning my sweet sister, therefore I trust my God that I will be able to achieve this, especially if the assembly in Kassa took place, claiming that my husband is ill, as he is, as if he was present at the assembly in your Grace's name [...], I would have a wonderful chance to carry out this plan. He [the groom candidate] was next to His Royalty in Tokaj as well, as Csáky says, who praises him moreover to be a good young man [...]. If only my God would allow him to become my kind brother-in-law, whom I could keep as my son. ${ }^{71}$

68 Kata Várdai to Anna Telegdi. Várda, Friday, 1623 (MNL OL, P 707, no. 9808)

69 Kata Várdai to Anna Telegdi. Várda, Tuesday, 1623 (MNL OL, P 707, no. 9811).

70 Krisztina Nyáry to Kata Várdai. Biccse, September 17, 1623 (MNL OL, P 707, no. 10705).

71 Anna Telegdi to Kata Várdai. Csicsva (Čičva, Slovakia), September 8, 1623 (MNL OL, P 707, no. 10872). 
While Anna Telegdi readily attempted to carry out her mother's plans, Kata Várdai soon produced an alternative candidate: Miklós Esterházy, who at the time was the second most influential political dignitary and who soon (in 1625) would become palatine of Hungary. Talks were underway with him at the time too, and Kata Várdai was seeking the advice of her son-in-law for on final decision. István Nyáry offered her the following reply:

Your Highness commands me to write whether I prefer Eszterházy or the other man from Kassa. For many reasons Eszterházy is better, but I do not trust this and cannot imagine any way to carry out this plan. I cannot tell about Lord Csuti of the affair either, the Eszterházy affair, since he does not like Eszterházy. We could achieve this in other ways too, if only my sister has not tied herself in the meantime to elsewhere, since I know well that a servant of my Lord Eszterházy is coming to my lady Highness with whom we can arrange the affair if both God and my sister want it.

István Nyáry passed on the latest news to his wife. ${ }^{72}$ While the married stepsiblings may have had doubts concerning the implementation of their "mother's" ambitious plans, they unbendingly supported her aim of getting back their sister and marrying her off again. Krisztina's happiness may well have been an important consideration, but so was the extension of the kinship network with the addition of another powerful in-law. Krisztina meanwhile found herself faced with other pressures: her mother-in-law was mapping the marriage market with the help of her in-law, Szaniszló Thurzó, the palatine of the kingdom (it was after his death in 1625 that Miklós Esterházy would become palatine).$^{73}$ In the summer of 1623, they were considering having their widowed daughterin-law marry Ferenc Liszti, the captain of Szamosújvár (Gherla, Romania) and Szaniszló's brother-in-law. ${ }^{74}$ In a letter to István Nyáry, Thurzó announced their intentions to the Várdai-Telegdi family, asking them to support their decision:

Last summer with my beloved wife ${ }^{75}$ we contacted your Grace and your Grace's beloved wife with our letters sent from Pöstyén, ${ }^{76}$ announcing our will that we want to marry the widow of the late Count Imre

72 István Nyáry to Anna Telegdi. Kassa (Košice, Slovakia), February 12, 1624 (MNL OL, P 707, no. 9681).

73 Szaniszló Thurzó (1576-1625) was a distant cousin of György Thurzó (1567-1616), the late husband of Erzsébet Czobor.

74 The Palatine Szaniszló Thurzó’s wife was Anna Rozina Liszti, whose first cousin was Ferenc Liszti.

75 Anna Rozina Liszti.

76 Piešt'any (Slovakia), one of the most spa towns of the region. 
Thurzó, my Lord Brother, to my Lord brother-in-law Ferenc Liszthius and also asking your Grace to promote the case with my lady Mrs. Pál Nyáry, ${ }^{77}$ on whose good will the issue depends. Your Grace has promised his great the support and solidarity of his kinsmen, in which we fully trust. We have written again to Mrs. Pál Nyáry about the same affair, and we assume that we will not be disappointed in our hopes, if her Highness displays her good will. Therefore, we request your Grace and your Grace's beloved wife (to whom we offer our services through your Grace) to recommend the case to my lady Mrs. Pál Nyáry so that we receive her kind answer. Your Grace should believe that we will gratefully compensate your Grace's trouble and kinsman's solidarity in all times. We recommend the affair also to the Prince of Transylvania, ${ }^{78}$ so that his Majesty can also propose our affair to my lady Mrs. Pál Nyáry, your Grace should not let his Majesty forget the case. We expect your Graces kind answer. ${ }^{79}$

Assuming that they were superior in power, the Thurzós make a rather extraordinary and even offensive request as if their wishes were merely the natural order of things. Finding a spouse for a woman who had been widowed was considered the responsibility of the families into which they were born, and it was only a question of decency and custom to ask the consent of the family of the deceased husband. ${ }^{80}$ Nevertheless, as the affair between the Thurzó and Várdai-Telegdi families suggests, the search for a new spouse for a young widow was in fact a power game, during which family relations were subject to negotiation. Obviously, chances for cooperation instead of conflict must have been better in cases in which the two dynasties belonged to the same dense network of marital allies and were connected in several ways. The self-confidence of the Thurzós, reflected in their bold request, was arguably a rhetorical tool intended simply to convince the rival family that they had no say in the matter or little chance of prevailing if they attempted to defy the will of

\footnotetext{
77 Kata Várdai, the widow of Pál Nyáry.

78 Gábor Bethlen, Prince of Transylvania (1613-29).

79 Szaniszló Thurzó to István Nyáry. Vienna, February 29, 1624. (MNL OL, P 707, no. 7964). Quoted in Slovak translation by Duchoňová, Palatín Mikuláš Esterbááy, 402. https://veda.sav.sk/kniha/duchonovadiana-palatin-mikulas-esterhazy-dvorska-spolocnost-a-aristokraticka-kazdodennost. Last accessed on September 22, 2020.

80 On how Erzsébet Czobor expressed her feeling of outrage at not having been asked to accept the marriage see Duchonová, "Nói családi szerepek," 51. In eighteenth-century Russia it was the right of the deceased husband's family to organize the wedding for the widow. (I would like to thank Barbara Alpern for this information.)
} 
the Thurzó clan. But they were aware of the fact that the Várdai-Telegdi family also wielded considerable influence, and they tried to overcome this by dividing their enemies. The stepson and son-in-law István Nyáry was approached in the hopes that he would be able to sway Kata Várdai, who was the decision-making matriarch of the family. ${ }^{81}$ István's phrasing implies that Krisztina did not refuse the idea of this marriage: she preferred to be reaffirmed as a member of the more powerful Thurzó kinship network as the wife of Ferenc Liszthius than to be compelled to marry the man her mother had found for her in the meantime, the young nobleman (whom I could not identify) in the Bethlen entourage.

At that moment, Kata Várdai was definitely losing the battle. The matriarch of Várda did not respond well to challenges to her authority. At the beginning of 1624, she launched a bold, new campaign, as a result of which, in February, the new candidate for Krisztina's hand in marriage was Miklós Esterházy, the best possible match, the new rising star on the cloudy sky of the divided kingdom. In other words, respecting neither God nor secular power (Esterházy was a Catholic, and he was the leader of the Habsburg-oriented political group), she won him as her daughter's second husband. He was a widow and 20 years her senior, and he would refer to her as "my son" until his death. ${ }^{82}$ This was a final blow to Erzsébet Czobor. The royal fiscus was just donating the ancient Thurzó lands, given the failure to produce a male heir, to the political rival of the late Imre Thurzó, Miklós Esterházy. ${ }^{83}$ And even though Esterházy was a parvenu among prestigious aristocrats like the Czobors, Thurzós and Várdais and they spoke about him among themselves with contempt ${ }^{84}$ mothers and widows were still locked in fierce contest for his hand. At his first wedding, in 1612, when he was still unaccustomed to the wealth he had gained through marriage, he made a cheeky show of this. Anna Telegdy, who was present for the wedding, wrote of this in a letter to her mother: "My dear lay mother, no one has presented any gifts, since Eszterházy refused to accept them, saying that he has enough wealth anyway." Anna also wrote to her mother of how she had been unable to resist the pressures put on her by the groom, and she had accepted the role of

\footnotetext{
81 István Nyáry to Anna Telegdi. Kassa, February 9, 1624 (MNL OL, P 707, no 9682).

82 Merényi, "Esterházy Miklós újabb levelei Nyáry Krisztinához," 354-86 and 481-512., passim.

83 Kubinyi, Betblenfalvi gróf Thurzó Imre. http://mek.niif.hu/05600/05613/html/. Last accessed on July $9,2020)$

84 When Krisztina told her mother-in-law the news of her upcoming wedding, Erzsébet Czobor reminded her of how shocked her mother and sister had been when Esterházy had wanted to marry Zsuzsanna Erdődy. Letter quoted by Duchonová, "Női családi szerepek."
} 
bridesmaid. ${ }^{85}$ Kata's new son-in-law, like her, was not lacking in willpower, which he learned to assert shrewdly and delicately, thus securing the loyalty of others and avoiding uses of force. Anna wrote of his generosity in a letter to her mother written twelve years later during the preparations for Krisztina's marriage: "I have received today from my lord Eszterházy a very nice pearl necklace and a diamond ring, and we gave him a handkerchief and a chief of flowers." 86

Krisztina was apparently not disturbed by the huge age gap. She decided to go home to her mother, leaving her daughters behind in the Thurzó court only once Esterházy had become her betrothed. Thus, maneuvering between the two family matriarchs, she managed to make the decision concerning who would be her second husband. Her distancing from her marital family is reflected by her newfound ability overtly to say no to her mother-in-law's requests, which she did more than once in her letters sent from her natal home following April 1624. This constituted a shift in the language of subordination that she continued to use. $^{87}$

Erzsébet Czobor, who was also very sensitive to the smallest challenge to her authority, sought like wounded animals to the end. Anna wrote of this in a letter to her mother five days before Krisztina's wedding at their curia in requests: "Mrs. Thurzó wanted to grab my sister from us and take her to the castle of Árva, ${ }^{88}$ only the palatine ${ }^{89}$ could stop her from holding the wedding there and having it consummated by Krisztina and Liszthius". ${ }^{90}$ Krisztina therefore needed to be attentively guarded: "My beloved lady mother, yesterday I sent the steward and the old woman [the head of the women's court] to Letava ${ }^{91}$ for some of my belongings, since I was not allowed to go myself." ${ }^{92}$ Esterházy had an entire army to escort him, and he oversaw the preparations himself. ${ }^{93}$ The successful outcome of the "battle," however, remained uncertain up to the very end: "People were rather afraid that the events will take another turn, [...]. God

85 Anna Telegdi to Kata Várdai. Szentmiklós (Beregszentmiklós, Чинадійово, Ukrajna), 1612 (MNL OL, P 707, no. 10870).

86 Anna Telegdi to Kata Várdai. Szucsány, July16, 1624 (MNL OL, P 707, no. 10876).

87 Duchonová, "Női családi szerepek," 52.

88 Oravský hrad, in north Slovakia, another castle of the Thurzó family,

89 Szaniszló Thurzó (1576-1625), palatine (1622-25).

90 Anna Telegdi to Kata Várdai. Szucsány, July 16, 1616 (MNL OL, P 707, no. 10876).

91 Castle of Lietava (Lietavský hrad, Slovakia), a nearby castle of the Thurzó family where Krisztina held her court.

92 Krisztina Nyáry to Kata Várdai. Szucsány, July 16, 1624 (MNL OL, P 707, no. 10707).

93 See the above letter of Anna Telegdi to her mother about their arrival and reception in Szucsány. Szucsány, July 16, 1624 (MNL OL, P 707, no. 10876). 
be praised, in modest silence, not blatantly, my dear lady mother, God's power is abundant and your Grace find calmness in her sweet motherly heart." ${ }^{\text {9 }}$

\section{The Half-Sisters}

Anna often played the role of caring mother not only with her mother but also with her sister. Given the large age difference between them, the elder half-sibling regularly found herself in the role of a mother. Anna seems to have played this caring role with the child (1610-1618), the wife (1618-1621), and the widow (1621-1624) Krisztina, too. ${ }^{95}$ She worried about her little sister when Krisztina was pregnant, much as a mother might have. ${ }^{96}$ Anna—not Kata Várdai-replaced the book of the gospels which had gone missing when Krisztina was confined to her sickbed: "What my sweet soul sister writes, I take with great joy, though they brought no money, but were I to set some aside, I will buy it for my soul. I will send the Gospels in Károly, ${ }^{97}$ the great national crowd will be there, when we arrive." ${ }^{\prime 98}$ After having worked with her mother for two years on her widowed sister's "liberation" and the task of finding her a second husband, in the end, in July of 1624, the task of tending to the preparations for the wedding also fell on her shoulders: "Our wains, my sweet lady mother, have not yet arrived, and this will be a great loss, for we do not have good vinegar. [...] Indeed, I face great difficulty, I have come not to a wedding, but rather to worry, they are dancing, drinking, I have to make a fortune from nothing." ${ }^{99}$ Reading these lines alongside Krisztina's letter written the same day, one senses some disapproval of her sister in her tone, as Krisztina played the role of a child next to her elder sister and enjoyed the lack of responsibility. Krisztina wrote, "We are quite happy here, the sick girls also danced away the cold. My Sweet loving Lady Mother, I know my loving sister informed your grace of everything." ${ }^{100}$ With the unusual manner in which she indicates the place in which the letter was written ("from Szucsány,

\footnotetext{
94 Ibid.

95 In the summer of 1624, Krisztina married again. Her second husband was Miklós Esterházy, the most prominent pro-Habsburg politician of the Hungarian aristocracy.

96 See the quote above (in footnote 118) from the Anna Telegdi’s letter to Kata Várdai. February 4, 1622. (MNL OL, P 707, no. 10862).

97 The town of Nagykároly (today Carei, Romania).

98 Anna Telegdi to Kata Várdai. Nagykálló, May 29, 1621 (MNL OL, P 707, no. 10859).

99 Anna Telegdi to Kata Várdai. Szucsány, July 16, 1624 (MNL OL, P 707, no. 10876)

100 Krisztina Nyáry to Kata Várdai. Szucsány, July 16, 1624 (MNL OL, P 707, no. 10707).
} 
with which I am bored"), Anna subtly hints to her mother that she is fed up with the motherly role she has had to play for her sister. ${ }^{101}$

Anna Telegdi could not openly express her negative feelings about her sister (her indignation in the passages cited above, perhaps a touch of jealousy in passages cited below) to her mother: "my sister was very happy indeed for the money your grace provided her, she will serve your grace as her loving lady mother, though thank God, she did not have great need of it, since the lady her greatness ${ }^{102}$ has given her a nice income, I cannot write your grace how pleased she was to see it." 103 There is an enigmatic sentence in a letter she wrote in February 1622, after her husband had brought her back from Biccse and Kata Várdai had remained with Krisztina, who was soon going to give birth: "I could write your grace of something quite wondrous concerning my sister, but as God gives me life, I am not an ill-willed sibling, about whom, with your grace coming before God, I will speak amply on whom your grace will marvel." 104 Anna was referring to her bewilderment at her sister's conduct. The fact that Kata Várdai was in a position to express negative feelings while Anna was not stems from the fact (and demonstrates) that Anna was in a position of subordination to her mother. She may have felt the compulsion to use veiled references instead of open communication because she had already learned that it was not worth expressing her true feelings bluntly, as they would be ignored or, in a worse-case scenario, she might even be punished for having voiced them. ${ }^{105}$

These veiled expressions of negative feelings came to the surface during the family negotiations after the death of Imre Thurzó and Krisztina's remarriage, but even in these conflict-laden periods, gestures of support and solidarity remained dominant in the relationship between the half-sisters. After the death of her first husband, Krisztina found herself in a difficult situation. Her motherin-law had been given guardianship over her two daughters and had essentially excluded her from the girls' upbringing in a manner that was extraordinary. She had also tried to assume control over the issue of Krisztina's potential remarriage. During these long two years, Anna worried a great deal about her widowed sister's fate: "Just that my sweet Krisztina Nyáry should live, and may the Lord

\footnotetext{
101 Anna Telegdi to Kata Várdai. Nagykálló, May 29, 1621 (MNL OL, P 707, no. 10859).

102 Erzsébet Czobor, Krisztina Nyáry’s mother-in-law.

103 Anna Telegdi to Kata Várdai. Beszterce (today Banská Bystrica, Slovakia), July, 1620 (MNL OL, P

707, no. 10850).

104 Anna Telegdi to Kata Várdai. Varannó, February 9, 1622 (MNL OL, P 707, no. 10863).

105 Berne, Games People Play.
} 
give her good fortune," she wrote in a letter to her mother. ${ }^{106}$ In addition, she took on numerous tasks in order to bring her sister home from the Thurzó court and ensure that she and her mother find Krisztina a second husband. Her own interests coincided with those of the family: another good match for her sister would serve to raise the social standing of every member of the family.

The rivalry and envy between the two sisters may well have been caused by the difference in their social ranks, which was a consequence of the different paternal inheritances of the maternal half-siblings and the differing statuses of their fathers' families. The comparatively modest estates left by Pál Telegdi to his daughter, Anna, in Bereg-Zemplén could not compete with the significant estates which Pál Nyáry left his daughter, Krisztina. ${ }^{107}$ The resulting inequality, however, was more or less offset by the two clever moves made by the mother, Kata Várdai, who became the head of the family as a widow. The respectable bequest left by István Báthori and the marriage between the stepsiblings, through which Anna Telegdi became István Nyáry’s wife, significantly improved Anna’s position. Krisztina's two marriages then elevated her well above her sister in social position in principle, but the prestige the two girls enjoyed as the wives of prominent men came largely from the family of their birth, which continued to expect loyalty and service from them. ${ }^{108}$ That is why, even when she was the wife of "count” Imre Thurzó and then of "count” Miklós Esterházy, Krisztina Nyáry still referred to herself as the "little sister who serves with a true heart" in her letters to her sister, which indicates her lower position in the family hierarchy. In other words, status in their relationship was determined primarily by their birth order, which typically meant a significant age difference for half-siblings. As we have seen, Krisztina became a playmate of her nephew, Ferkó, who was much closer to her in age, while her elder sister played a motherly role at her side, and she continued to play this role even after Krisztina had married. Krisztina herself associated Anna's performances of loving concern with Anna's role as a mother figure: "In this very hour your grace's humble servant Kristóf Egry has arrived, and I understand from what he says that you are very worried about my sick state. Indeed, I believed him, sweet loving sister, for like my dear mother, your grace has always had such a kind heart to me." 109 The letter which Krisztina wrote to her mother differ little from the letters that she wrote to her sister. She was able to

106 Anna Telegdi to Kata Várdai. Csicsva, September 14, 1623 (MNL OL, P 707 10874).

107 Benda, Nyáry Pál és Várday Kata leveleeése, introducton.

108 See Ruppel, Verbündete Rivalen, 219.

109 Krisztina Nyáry to Anna Telegdi. Zsolnalitva, July 19, 1620 (MNL OL, P 707, no. 9697). 
count on compassion and consolation when she wrote of the unpleasant feeling she had in her husband's court of being a stranger. Her sister passed on these concerns to her mother, as if it were considered self-evident that she would do so: "My sweet lady mother, as my letter will make clear to you concerning my dear sister's state, I sincerely pity her sweet soul when she writes that she had no other music than the howling of the wolf, of whom I know God has so far consoled her, because lord Thurzó [Imre Thurzó, Krisztina's husband] went home. ${ }^{110}$

However, the exceptional, playful, even joking tone of Krisztina's letters to Anna, which seems more the tone of an exchange between equal partners than an exchange between people in a vertical hierarchy, is a clear break from the register of a mother-daughter relationship. The following lines offer a glimpse into the moment when the hierarchy between the two sisters was suspended:

Sweet, loving, dear lady sister, I understand from your letter that your grace found Lady Mihály Czobor ${ }^{111}$ in Pricopan, ${ }^{112}$ and your grace merrily lived with her, only your grace caused sadness in my heart, when I thought of how in this merriment we cannot be together with sweet Katica Thurzó, ${ }^{113}$ I could not bear it without shedding tears. Sweet, dear lady my sister, I ask your grace, let us not be forgotten by your grace, let us be in your grace's memory, if not every time, then at least when your grace sits into the baths. ${ }^{114}$

\section{Conclusion}

The cultural context of the relationships discussed above between female family members (mother and daughter, mother-in-law and daughter-in-law, sisters) was the domestic space, which in this case was the aristocratic female courts.

110 Anna Telegdi to Kata Várdai. Kassa, January 29, 1620 (MNL OL, P 707, no. 10843). Nine of Krisztina's letters to Anna have survived from the period between 1619 and 1633 (MNL OL, P 707, no. 9696-9704). Seven were written before 1624, and two were written in her own hand (no. 9700-01). Anna's letters to Krisztina have not survived.

111 Mihály Czobor (1575-1616) was Erzsébet Czobor's younger brother. As his second wife, he took his stepdaughter, Zsuzsanna Thurzó, who was 13 years younger than he (she was the widow of István Perényi). Thus, Zsuzsanna Thurzó was Krisztina's sister-in-law.

112 Révayfalva, or Prékopa by its Slovak name, is today part of the city of Túrócszentmárton (today Martin, Slovakia). Near this, one finds Stubnyafürdő (today Turčianske Teplice, Slovakia), to which the author of the letter is referring.

113 Katica Thurzó, Imre Thurzó's younger sister, was Krisztina's sister-in-law at the time (she herself was still unmarried). They were close in age, and Katica was a friend of Krisztina's in the court in Biccse.

114 Krisztina Nyáry to Anna Telegdi. Biccse, May 29, 1619 (MNL OL, P 707, no. 9696). 
Letter exchanges between female family members have drawn the contours of this pragmatic and intimate kinship network, which functioned alongside the hegemonic patrilineal family and which was organized and inhabited by women, their central figures being mothers and their daughters. This alternative female space and horizontal web of relations may have rendered the marginal status of women in the patriarchal family more livable, since the central role of female networks in making marriages, mediating conflicts, and forming public opinion offered them a significant form of power. ${ }^{115}$ Thus, I suggest that the longevity of the patriarchal family across centuries can perhaps be attributed not only to its inner "structures of mitigation," its own flexibility, as Linda Pollock has argued, but also to these alternative female networks and the connections between sisters and sisters-in-law, cousins, and female friends, which contributed to its sustainability. ${ }^{116}$

We have seen Krisztina Nyáry negotiating her mediating role as wife between her two families and two "mothers," and the letters exchanged by the sisters and their mother also offer insights into her tactics of gaining the support of her mother by painting a dramatic image of herself as a vulnerable widow. Her excessive use of a stereotypical self-representation as a vulnerable widow may indicate her lack of trust in her short-tempered mother, who was unable to provide unconditional love and predictable support for her daughters due to her narcissistic personality. We also saw how, by maneuvering shrewdly between the two dominant mother figures, Krisztina was ultimately able to make the decision concerning her second husband herself.

One of the general lessons of our case study is, therefore, that women's inbetween position between their natal and marital lineages and their marginality in the patrilineal family could be appropriated by individuals for their own purposes. How widows were reintegrated into the hegemonic family system via their remarriage (assuming that they did remarry, as most widows under the age of $40 \mathrm{did}$ ) depended greatly on their own choices and performances, too. Though the mother-in-law's efforts to reintegrate her wealthy daughter-in-law into her own alliance network may seem exceptional, it was obviously possible, even if Krisztina's natal family happened to win the rivalry in this particular case. In other words, the remarriage of widows was a negotiating process depending on power relations rather than on static norms or family structures.

115 On female authority acquired via the workings of female networks, see Herbert, Female Alliances, passim.

116 Pollock, "Rethinking Patriarchy." 
The elder half-sister offered gestures of maternal care not only to her mother, who often assumed the role of the child, but also to her younger sister. The structural asymmetries of their age, rank, and distance from their mother notwithstanding, the maternal half-sister bond operated on a basis of strong emotional and familial solidarity rather than rivalry. The continuity of the maternal role played by Anna Telegdi throughout Krisztina's childhood, adulthood, and widowhood suggests, moreover, that married women remained in close connection with their natal families.

The manner in which Anna consistently played a motherly role in her relationship with her sister, even during the consecutive life-cycles of Krisztina, plausibly suggests that married women continued to maintain strong bonds with their natal families. This was of particular importance for Krisztina, who was only loosely integrated into her husband's family. The intermediary role played by Krisztina between her two families and the greater spatial and emotional distance from her mother (in comparison to Anna, who lived in the same household as their mother and was thus arguably more dependent on her wishes and her goodwill) rendered her more capable of defending herself from their mother's anger and emotional abuses. The close reading of the mother-daughter debates highlights, furthermore, that in the religious climate of the seventeenth century, alongside the notion of unconditional maternal (or, more generally, parental) love, the concept of conditional love was also accepted.

\section{Archival Sources}

Magyar Nemzeti Levéltár Országos Levéltára [Hungarian National Archives] (MNL OL), Budapest

P 108. The archives of the princely lineage of the Esterházy family

P 707. The Archive of the Zichy Family, Correspondence

Országos Széchényi Könyvtár [National Széchényi Library], Budapest

Manuscript Collection, Fol. Hung. vol. 2638/2. The collection of copies of letters by Hungarian women

\section{Bibliography}

Balogh, Zsuzsánna. “Özvegység, újraházasodás és testvéri kapcsolatok egy 17. századi erdélyi nemesasszony levelezésében" [Widowhood, remarriage and sibling relations in the correspondence of a seventeenth--century noblewoman]. In Özvegyek és 
árvák a régi Magyarországon 1550-1940, edited by Gabriella Erdélyi, 227-46. Magyar Családtörténetek: Tanulmányok 5. Budapest: BTK, Történettudományi Intézet, 2020. Benda, Kálmán, ed. Nyáry Pál és Várday Kata levelezése 1600-1607 [The correspondence of Pál Nyáry and Kata Várday, 1600-1607]. Debrecen: Kisvárdai Vármúzeum, 1975.

Berne, Eric. Games People Play: The Psychology of Human Relations. London: Andre Deutsch, 1965.

Bódai, Dalma. "Szülői szerepek és gondoskodás: Czobor Erzsébet mint anya és mostohaanya" [Parenting roles and caregiving: Erzsébet Czobor as mother and stepmother]. In Érzelmek és mostohák: Mozaikcsaládok a régi Magyarországon, 15001850, edited by Gabriella Erdélyi, 91-111. Budapest: BTK Történettudományi Intézet, 2019.

Broomhall, Susan, and Jacqueline Van Gent. Gender, Power and Identity in the Early Modern House of Orange-Nassau. London and New York: Routledge, 2016.

Chabot, Isabelle. "Seconde nozze e identita materna nella Firenzae del tardo medieoevo". In Tempi e spazi di vita femminile tra medioevo ed eta moderna, edited by Silvana Seidel Menchi, Anne Jacobson Schütte, and Thomas Kuehn, 493-523. Bologna: Il Mulino, 1999.

Duchonová, Diana. "Női családi szerepek: menyasszony, feleség, anya. A női kommunikáció színterei a nemesi családokban" [Familial roles of women: bride, wife, mother. The scenes of female communication in noble families]. In $A$ nố kommunikáció kultúrtörténete. Tanulmányok, 47-58. Budapest: Napvilág, 2019.

Duchoňová, Diana. Palatín Mikulás Esterházy: Dvorská spoločnost' a aristokeratická každodennost'. [Palatine Miklós Esterházy]. Veda, 2017.

Erdélyi, Gabriella. "Confessional identity and models of aristocratic conversion in seventeenth- and eighteenth-century Hungary.” Social History 40 (2015): 473-96. doi:10.1080/03071022.2015.1080009.

Erdélyi, Gabriella, ed. Özvegyek és árvák a régi Magyarországon, 1550-1940 [Widows and orphans in Hungary, 1550-1940]. Magyar Családtörténetek: Tanulmányok 5. Budapest: BTK, Történettudományi Intézet 2020.

Erdélyi, Gabriella. "Stepfamily Relations in Autobiographical Writings from SeventeenthCentury Hungary." In Stepfamilies in Europe, 1400-1800, edited by Lyndan Warner, 146-67. Abingdon: Routledge, 2018.

Forward, Susan, and Donna Frazier. Emotional Blackmail: When the People in Your Life Use Fear, Obligation, and Guilt to Manipulate You. New York: Harper Books, 1998.

Harris, Barbara J. English Aristocratic Women, 1450-1550: Marriage and Family, Property and Careers. New York: Oxford University Press, 2002. 
Herbert, Amanda E. Female Alliances: Gender, Identity, and Friendship in Early Modern Britain. New Haven and London: Yale University Press, 2014.

Horn, Ildikó. "Nemesi árvák a kora újkorban" [Noble orphans in early modern Hungary]. In Gyermek a kora újkori Magyarországon, edited by Katalin Péter, 51-90. Budapest: MTA Történettudományi Intézet, 1996.

Ipolyi, Arnold. Bedegi Nyáry Krisz̨tina, 1604-1641 [Krisztina Nyáry of Bedeg, 1604 1641]. Budapest: Franklin Társulat, 1887.

Klapisch-Zuber, Christiane. "The 'Cruel mother': maternity, widowhood, and dowry in Florence in the fourteenth and fifteenth centuries." In Women, family, and ritual in Renaissance Italy, edited by Christiane Klapisch-Zuber, 117-31. Chicago: University of Chicago Press, 1985.

Kubinyi, Miklós. Bethlenfalvi Gróf Thurzó Imre, 1598-1621 [Count Imre Thurzó of Bethlenfalva, 1598-1621]. Budapest: Franklin Társulat, 1888.

Merényi, Lajos. "Esterházy Miklós újabb levelei Nyáry Krisztinához. Első és második közlemény" [Letters of Miklós Esterházy to Krisztina Nyáry. First and second publications]. Történelmi Tár, no. 49 (1901): 354-86 and 481-512.

Pálffy, Géza. “A Thurzó család a Magyar Királyság arisztokráciájában” [The Thurzó family in the aristocracy of the Kingdom of Hungary]. Történelmi Szemle 53, no. 1 (2011): 63-84.

Peltonen, Matti. "Clues, Margins, and Monads: The Micro-Macro Link in Historical Research." History and Theory 40, no. 3 (2001): 347-59.

Péter, Katalin. "Az asszony neve. Arisztokrata névhasználat a 16-17. századi Magyarországon" [The name of the woman: The usage of names among aristocrats in Hungary in the sixteenth and seventeenth centuries]. Történelmi Szemle 52, no. 2 (2010): 151-87.

Pollock, Linda A. "Rethinking Patriarchy and the Family in Seventeenth-Century England." Journal of Family History 23, no. 1 (1998): 3-27.

Ruppel, Sophie. Verbündete Rivalen: Geschwisterbeziehungen im Hochadel des 17. Jahrhunderts. Cologne-Weimar-Vienna: Böhlau, 2006.

Schneider, Gary. The Culture of Epistolarity: Vernacular Letters and Letter Writing In Early Modern England, 1500-1700. Newark: University of Delaware Press, 2005.

Spieß, Karl-Heinz. Familie und Verwandtschaft im deutschen Hochadel des Spätmittelalters: 13. bis Anfang des 16. Jabrbunderts. Stuttgart: Franz Steiner Verlag, 2015.

Warner, Lyndan. "Conclusion. Continuity and change in stepfamily lives, 1400-1800." In Stepfamilies in Europe, 1400-1800, edited by Lyndan Warner, 233-64. London and New York: Routledge, 2018. 